\title{
Pandemic; Collateral Damage In The Hotel Sector Of The City Of Cuenca
}

\section{Pandemia; Daños Colaterales en el Sector Hotelero de La Ciudad de Cuenca}

\author{
Marcelo Andrés Lucero Salamea ${ }^{1}$, Gliceria Petrona Gómez Ceballos²
}

${ }^{1}$ Ingeniero Comercial, Universidad Politécnica Salesiana, Cuenca, Ecuador.

2 Doctora en Ciencias Económicas, Universidad Politécnica Salesiana, Cuenca, Ecuador.

* Corresponding author (E-mail corresponding author): mluceros2Aest.ups.edu.ec

\section{ABSTRACT}

COVID-19 has generated great economic losses to world tourism, among them, the hotel sector has been seriously affected, since as a result of the pandemic its activity has decreased significantly, a situation to which the city of Cuenca in Ecuador selected as object of study for the development of this research, has not been foreign, the objective of the same was formulated as, to determine levels and causes of the economic affectation in the hotel sector of the city caused by the pandemic, as a basis for the improvement of its management in the face of crisis scenarios, supported by the use of methods linked to risk studies; The methodology used was descriptive analytical type, through the use of qualitative and quantitative methods; For the analysis, a questionnaire focused on hotel managers and owners was carried out, the results of which show a significant deterioration in the economic indicators, generating an increase in the unemployment rate, in addition, there is insufficient management and forecasting of risks motivated because the staff does not He is trained in this area, concluding that the impact due to the lack of risk prevention strategies is high, a situation that causes significant losses for the city.

Keywords: COVID-19, Risks, Tourism, Hotel Sector, Economic Impact.

\section{RESUMEN}

La COVID-19 ha generado grandes pérdidas económicas al turismo mundial, entre ellos, el sector hotelero ha sido seriamente afectado, ya que como consecuencia de la pandemia se ha disminuido sensiblemente su actividad, situación a la que la ciudad de Cuenca en Ecuador seleccionada como objeto de estudio para el desarrollo de esta investigación, no ha estado ajena, el objetivo de la misma se formuló como, determinar niveles y causas de la afectación económica en el sector hotelero de la ciudad provocada por la pandemia, como base para el perfeccionamiento de su gestión frente a escenarios de crisis, soportado en el empleo de métodos vinculados a estudios de riesgos; la metodología utilizada fue de tipo analítica descriptiva, mediante la utilización de métodos cualitativos y cuantitativos; para el análisis se realizó un cuestionario enfocado a los directivos y dueños de hoteles, cuyos resultados muestran un deterioro significativo en los indicadores económicos, generando un aumento en la tasa de desempleo, además, existe insuficiente gestión y previsión de riesgos motivado porque el personal no está capacitado en ese ámbito, concluyendo que la afectación por falta de estrategias en prevención de riesgos es alta, situación que provoca importantes pérdidas para la ciudad.

Palabras clave: COVID-19, Riesgos, Turismo, Sector Hotelero, Impacto Económico. 


\section{INTRODUCTION.}

The World Health Organization defines the Coronavirus (COVID-29) pandemic as "... the infectious disease caused by the coronavirus that has been discovered more recent$l y$, the new virus as the disease were unknown before the outbreak broke out in Wuhan (China) in December 2019..." (WHO, 2019). In this sense, the WHO declares the outbreak of COVID-19, as a public health emergency of international concern on January 30, 2020 and on March 11, 2020, as a global pandemic because the virus spread in more than 100 cities, faced with this situation, governments were forced to establish different restrictions in relation to domestic and international flights, quarantines and confinements of their citizens, all in order to safeguard the integrity and health of citizens and prevent the collapse of health systems worldwide (PAHO / WHO, 2020), this is the first pandemic of the twenty-first century that highlights the continuous high risks and vulnerability of the mundial population , therefore, as mitigation measures, the world's leaders decided to establish strategies of total isolation and the closure of borders, with the intention of trying to flatten the curve of contagions (UNDP, 2020).

According to data from the Ministry of Tourism (MINTUR), Ecuador in 2018 received a total of 2,535,140 tourists compared to 2017, so the entry of tourists had an increase of $40.4 \%$, while in 2020 and the first quarter of 2021 , the flow of visitors to the country decreased markedly, in 2020 a total of 507,333 people visited the country and in the month of March 2021 only an approximate number of 64,524 visitors was registered; in comparison with the influx of visitors in 2018, therefore, there was a decrease of $-87.3 \%$, as a result mainly of the mobility restrictions applied by the National Government, which have notoriously affected the tourism - hotel sector of the country (Ministry of Tourism, 2021).

Deepening in the analysis of these figures, the statistics of this ministry reveal that the most serious decrease in tourist arrivals to the country corresponds to the United States as the main source market, Venezuela shows a high rate of entries, but this more than anything are due to the fact that people from this country emigrate to Ecuador, in search of new opportunities to better their quality of life; Colombia, Peru and Spain are other markets that have contracted and they contribute significantly to the entry of tourists.
The data cited above, reflect a dramatic impact on the hotel sector, therefore, it is considered appropriate to closely analyze the economic reality suffered by this sector specifically in the city of Cuenca, since the beginning of the spread of the COVID-19 virus, since the city is currently positioned as a tourist destination with attractive resources in the historical, cultural and heritage order; the purpose of this study is to determine the monetary losses that the hotel field of the city has suffered, as well as the level of unemployment that the pandemic has generated by the decrease in tourists and by the cancellation of activities and closure of companies, motivating entrepreneurs and hotel owners to see themselves in the need to adapt to the changes in the variables of the environment , such as the adaptation to the new normal and the semaphorization of activities, which has encouraged the search for strategies to activate the economy.

The situation of crisis caused by the pandemic has called into question, the lack of foresight of the hotel sector in the face of threats and risks that had us mitigation actions, for this reason it is appropriate to analyze this factor as one of the variables of the study.

With regard to the risk management approach, Kessler and Prince (2018) suggest that risk prevention within the hotel sector should be comprehensively addressed and analyzed, as it is an important part of corporate safety and successful risk management can avoid dangers such as fires, falls, injuries, natural disasters and pandemics, preventing them directly contributes to the continuity of the business turn; it helps to avoid negative results by ensuring the safety of both personnel and their infrastructure.

In this sense, Núñez (2021) maintains that hotels, due to the same fact of not carrying out a descriptive analysis on their risks (endogenous and exogenous), have been affected by the materialization of incidents of various kinds. In the fact that they do not have specialized mitigation and contingency plans for each type of risk, they have incurred material expenses and losses, which in the worst case have resulted in the closure of activities.

At present, the COVID-19 pandemic is a risk of highdanger, for whose face the world was not prepared, fundamentally due to the lack of knowledge of strategies against disas- 
ters and threats of a global pandemic, which has caused countless businesses linked to the offer of accommodation services to close their doors, generating great monetary losses for the sector and for the economy in general of the countries (García, Reinoso and Vera, 2020).

Of the above and taking into consideration the serious consequences that this crisis has caused, the objective of this study proposes to determine levels and causes of the economic impact on the hotel sector of the city of Cuenca caused by the "COVID-19" pandemic, which then allow to define strategies for the improvement of hotel management putting them in capacity to overcome scenarios of this nature, analyzing the use of methods and tools appropriate to risk management.

Therefore, the following are defined as research questions: How is the risk management process handled in the hotel sector?

How did the "COVID-19" pandemic affect the hotel sector of the city of Cuenca?

The results show that due to COVID-19 the tourism-hotel sector of the city of Cuenca experienced a significant reduction in its economy, mainly due to the lack of economic income, the partial and / or total paralysis of establishments to not be able to cover the operating costs seriously impacting on local unemployment. The mitigation and contingency measures in the face of threats and risks were not taken into account by the hotels, which could have an influence on the impacts caused by the pandemic.

\section{CONCEPTUAL FRAMEWORK}

The United Nations Statistical Commission (2017) conceptualizes tourism as: "The activities carried out by people during their travels and stays in places other than their usual environment, for a consecutive period of time of less than one year, for leisure purposes, for business, and other reasons"(p. 143).

Pousada, Lindoso and Vilar (2020) affirm that, the tourist phenomenon is born from the ancient age because since then there were already tourist displacements, in a way the Greeks gave an important role to tourism, motivated by their preferences of leisure and sports, being in the Middle Ages where trips dedicated to pilgrimages of religious devotions flourish, being thus tourism was characterized or with the proliferation of places of accommodation dedicated to personalities of the time who moved with their entourage of followers and needed places for their stay; with the industrial revolution several determining factors are incorporated in favor of the development of tourism, such as, the reduction of costs by mobilization as a result of the rise of the steam engine that speeds up transportation and , in the twentieth century technological advances in this sector standout, given the manufacture of automobiles and the emergence of air transport.

In this context it is highlighted that tourism is a social phenomenon and a lucrative economic activity, which was in a stage of growth and development, until the appearance of the pandemic in 2019, as the tourist movement and spending were continuously increasing, together with this, there was an increase in competition between countries or regions of destination; given the panorama that the tourism sector was going through, it was also found that consumers already admitted changing behaviors focused on greater knowledge of available offers and non-traditional tourist destinations, tourists generate greater requirements and higher expectations, consumers are increasingly sensitive to the price war that is a consequence of the excess of offers in traditional destinations (Maciel et al, 2020).

Already warned, Lerbinger (1997) when he indicates that the research around the process of tourism management has shown that it is a sector prone to withstand crises, so that all actions aimed at safety, technology, hygiene are factors that the tourism sector pay special attention to minimize the appearance of crises. In events of this nature, threats affect all relevant groups in aspects related to impacts, experiences, socio-economic development and benefits.

Accordingly, Muñiz and Brea (2010) emphasize that sustainable tourism development could be aligned with risk management criteria that allow the identification of threats and opportunities in the environment and thus minimize crisis situations; in this sense, the application of risk analysis in the context of tourist destinations allows to make visible new opportunities to achieve better competitiveness and sustainability; 
In the same way, (Luque and Pellejero 2019) considers that crisis analysis involves defining types of alerts and indicators to be processed efficiently to achieve the reduction of crisis events, in this case, computer applications and communications have evolved in the aspects of information and reserves, being aspects that must also be managed with risk analysis to avoid the expansion in the chain of crises.

Among the components of tourism, is the hotel industry strictly related to criteria of lodgings of customers passing through the localities, activity carried out for several centuries. Díaz (2017) indicates that the oldest data related to lodging are originally from ancient Greece, by the Olympics, then, in the nineteenth century appear the hospitality spaces to meet the needs of travelers, later, the commercial activities of the hotels represented positive returns in the economies of the countries.

Thus, this sector is very solicitous, with various lodging services that require an organized and well-structured schemer within which, there are several specific positions and functions, which serve so that they can ensure maximum profitability, either in rooms, bars and / or restaurants. Woods and Viehland (2000) points out that, the managerial functions to be considered in hotel management are the general management, sales and marketing department, finance and food and beverage management, the correct distribution of functions contribute to the administration of a hotel, the same one that is with the responsibility of the general manager, who assigns specific responsibilities to his work team. From the first moment the employee begins his working relationship with the hotel, the manager must encourage the creation of a culture focused on the quality of service provision, creating standards that not only meet the expectations of the client, but that exceed them.

Anon (2020), suggests that the management of hotel accommodation in tourism comprises a series of processes that affect the functioning of the organization, having to optimize the operating procedures, therefore, to facilitate the development within the hotel management must be carried out an adequate study of the services offered to customers who demand it, the same ones that must be classified in an orderly manner so that the treatment of suppliers, transport and storage can be analyzed and evaluated. The execution of these processes must be aligned with the global strategic plan that is based on the maximum possible information of the market, linked to their socio-economic status, their food and beverage preferences, the level of customer satisfaction, the hotel services offered, the modalities of tourism that customers demand.

Currently, new, more agile forms of management have been adopted, such as integrated management programs, management supported by statistical methods and other ways to maximize the potential of the hotel.

Following the line of thought expressed by the authors, in the context of the business environment, hotel businesses must involve the interconnection of the different sections of the business and the different activities that make up its value chain due to the complexity of its functional structure, which must be aligned to policies of order and control that guarantee the quality of service; the hotel sector is an essential part of the value chain of tourism businesses within the territory, as its infrastructure, service and capacity entails the positioning of a city as a tourist destination, whether local, national or international (UNWTO 2020).

Among the aspects to be considered in hotel management, is the risk analysis of the different scenarios that are generated in this economic activity since its emergence; Romero (2003), highlights that mass tourism began in the period of the 50s, transformed the standard of living of the countries, promoting the improvements of the economies in benefit or of the residents and those who arrive or are passing through, achieved a greater rapprochement between women and men from all over the world; however, however, the scenarios have changed in recent years because there have been serious economic difficulties due to the period of crisis and global recession, although it continues and showing expansion, through a continuous evolution focused on the permanent development of projects; a situation that changes drastically from the end of 2019.

In recent times crises and global competitiveness have generated serious consequences, customer preferences are in a constant change, with the growing flow of tourists, accommodations and the tourism sector, have been forced to maintain constant learning, customers have learned to choose the best options by taking precedence over the desire for quality, safety and comfort (Chan, Gameros and Mena 2015). 
Likewise, the author states that in the face of any type of crisis, the main thing is the implementation of actions that ensure safety at work, protection and hygiene, and the application of safety actions related to natural disasters and the environment, the risk analysis that minimizes the affectation to personnel, equipment, facilities, it must be taken into account that productivity is a function of the work activity being carried out safely, so as not to affect the quality and efficiency of the services provided; all these risks can be minimized as long as there is a correct and effective management of the hotel management process , the diligence of the activity of safety and health at work depends on the leadership of the management, since it is one of the decisive factors for the achievement of the main objective (Piñeros, González and Ruíz, 2016).

In this regard, Kessler and Prince (2018) mention that the fundamental priority of risk management in hotels, is the safety of guests, employees and facilities, to achieve this objective in order to safeguard the integrity of people, a "Comprehensive Security Plan" must be designed and implemented that allows the mitigation of risks, it must establish a compromise between the material and personal. The World Economic Forum (2005) identifies three types or sources of disasters, which can cause major impacts on the tourism sector and can be classified as risks:

"(...)

- Environmental (natural disasters such as earthquakes, floods and man-made disasters such as oil slicks and fires)

- Geopolitical (terrorism)

- Social (pandemics and epidemics)

(...)"

On the other hand, Tourism (2020) describes, three types of risks:

- Market risk: fluctuation of supply and demand

A. Exchange rate risk (economic, political and health crises)

B. Interest rate risk (political and family)

- Credit risk: losing long-term agreements due to lack of working capital

- Liquidity risk: economic losses

Faced with this situation,(Hontalvilla, Lado and Vivel, 2018) indicate that: "risk management is the coordinated activities to direct and control the organization in relation to risk" (p. 4).
Beltrán (2018) adds that over the years the hotel sector and resorts have had to face different risks, ranging from the probability of having fires, natural disasters to thefts, for this reason, for there to be a good performance and functioning of the accommodation, the protection and safety of the guest have to be part of the basic service offered by the establishments, it is more frequent, that guests not only consider the good conditions of cleanliness, the quality of the service or the presentation in the food, but also, the security conditions that the hotels provide when facing a possible risk, so, a guest must enjoy their stay without feeling of danger, fear or insecurity.

The key to success for the hotel sector is to anticipate any type of incident or risk, which may cause impacts to the hotel or tourist center in the event of an event, not proceeding in this way, will be a clear reflection of the mismanagement of the hotel in terms of risk prevention, therefore, it will negatively affect the reputation of the establishment, this is mitigated, if the implementation of security policies and manuals is managed, for its prevention or mitigation (Beltrán,2018).

Tourism (2020) refers to the hotel sector taking the firm decision to implement risk management through measures aimed at minimizing it. Risk management must be part of all business subsystems, with processes well interconnected with each other. The management levels the managers of the hotel organization, will develop a "Contingency Plan" based on the risk assessment, which detaiIs the activities adopted to reduce vulnerabilities, insists that companies must define committees for the analysis and management of risks that have legal representation of workers and aligned with current regulations for the prevention of occupational risks. Once the risks have been identified and evaluated, the committee will apply the strategies and decision-making for their minimization, in particular the general manager must reduce the probability of risks by focusing on applying improvements to hotel management through methodologies that allow:

- Institute the objectives.

- Implement the mechanisms to gather the information that allows you to make the best decisions (consultations with the authorities, employees, specialists, etc.)

- Build the form of coordination between committee members and workers representatives.

- Outline the protection measures, within the contingency plan. 
Implementation and implementation of the contingency plan, depending on the size and complexity of the company through the supervision of the health authorities in relation to special measures due to COVID-19.

\section{METHODOLOGY}

The locality selected as a case study is the city of Santa Ana de los Ríos de Cuenca, (Cuenca 2017), capital of the province of Azuay, with its limits, to the North with the province of Cañar, to the South with the province of Loja, to the East with the province of Morona Santiago and to the West with the provinces of El Oro and Guayas; the city consists of $124 \mathrm{~km}^{2}$ of territorial extension with a population of approximately 580,000 inhabitants. Cuenca is listed as a city with a tourist vocation since it has a great variety of attractions, which make the visit by tourists unique and unforgettable. It has cultural and architectural wealth that are found in extensive natural spaces, in which archaeological vestiges can be found, being since 1994 as "Cultural Heritage of Humanity", this decoration added value to its positioning as a tourist destination.

The following graph shows map of your geographic location.

Figure 1: Geographical location of the city of Cuenca.

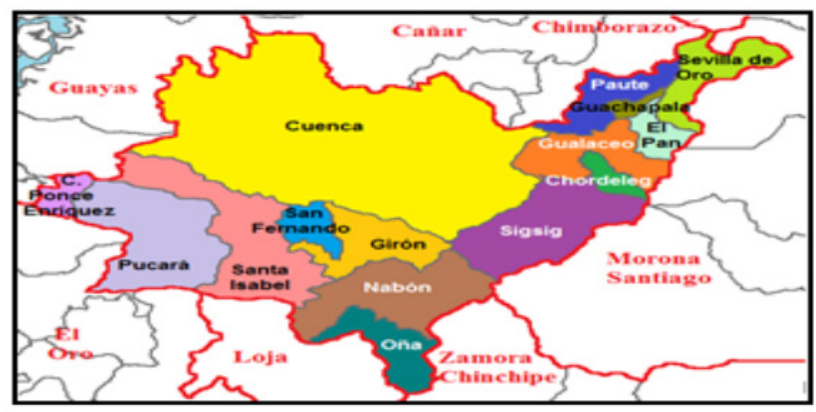

Source: Cuenca Alcaldía website (2018)

The city receives a great variety of foreign tourists, the most representative being those from:
Table 1: Percentage of visitors to Cuenca by country of origin

\begin{tabular}{|lc|}
\hline Country & Percentage of visitors to Cuenca \\
\hline United States & $25,7 \%$ \\
\hline Colombia & $9,5 \%$ \\
\hline Venezuela & $5,9 \%$ \\
\hline Peru & $4,6 \%$ \\
\hline French & $7,8 \%$ \\
\hline Germany & $7,2 \%$ \\
\hline Spain & $6,2 \%$ \\
\hline Rest of the world & $33 \%$ \\
\hline
\end{tabular}

Source: GIER statistical data (2019).

The methodology used is based on the approaches of Bernal (2011) and type of applied research was mixed, interrelating the qualitative methods to deepen the evolution of the phenomenon studied from the perspective of the perception of the actors involved in the hotel management process and quantitative to measure the variables selected for the study; with a transversal, purposeful and multidisciplinary approach.

The variables selected in correspondence with the research questions asked were:

- Independent: Risk management process.

- Dependent: Results of selected indicators.

- The period taken as the basis for the analysis was: the years 2019 and 2020.

Empirical methods were used for registration, qualitative measurement, document analysis; case studies and theoretical methods for the understanding of scientific theory, identification of regularities and essential characteristics of the study phenomenon.

Information gathering techniques were used in primary sources through a questionnaire, which was applied to hotel managers in order to delve into the root causes of the problem linked to the absence of risk management and strategies to deal with the crisis, in particular the current pandemic and , techniques for the collection of secondary information from the analysis of economic reports of the selected hotels, as well as review of specialized journals 
and literature, which contributed to the interpretation of the evolution of the object of study and identification of regularities in its behavior.

For the execution of interviews, digital alternatives were used due to the pandemic, such as video calls and videoconferences, taking care of the health of the interviewee and the interviewer.

The population selected for the study were the two- to five-star hotel businesses located in the city of Cuenca registered in the MINTUR cadastre (2020), according to the formula for obtaining simple sampling(Mendenhall, Beaver and Beaver, 2010),out of a total of 94 accommodations, a sample of 47.75 hotels is obtained as a unit of analysis, where a $10 \%$ margin of error and a $90 \%$ reliability margin is considered.

\section{RESULTS}

The results are presented in correspondence with the research questions asked in the study:

\section{1. - How is the risk management process handled in the hotel sector?}

The information regarding this research question from the perspective of descriptive analysis, took into account: The perception of the importance of risk management shown in Figure 2, availability of risk management strategy shown in Figure 3, importance on the need to implement a capitation program linked to risk prevention, shown in Figure 4, and criteria on the type of risks faced by hotels shown in Figure 5.

Figure 2: Importance of risk management in the hotel sector.

Indique en qué medida Ud. considera que seria importante incorporar una estrategia de gestión de riesgos en el sector hotelero

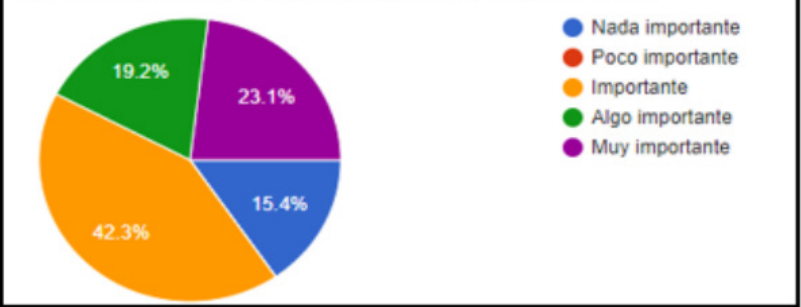

Source: Data analyzed based on primary sources
Figure 3: Do hotels have risk management strategies?

¿El hotel cuenta con estrategias de gestión de riesgos?
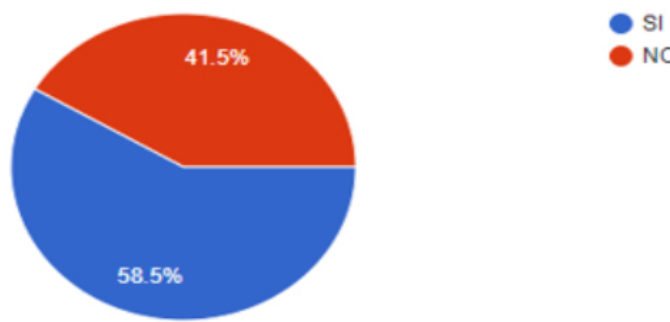

NO

Source: Data extracted from primary sources

Figure 4: Importance of a training program to prevent potential risks

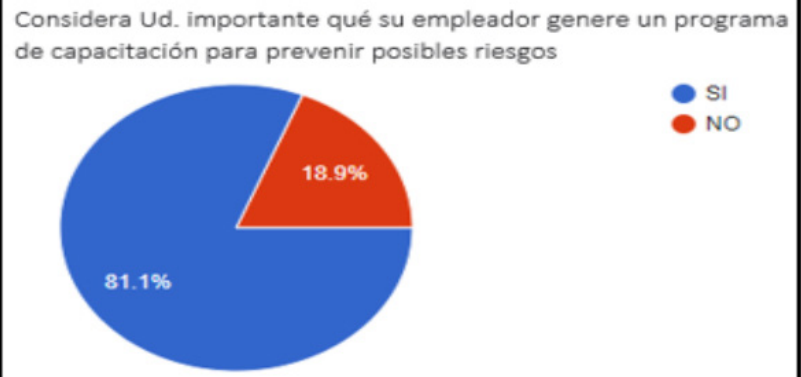

Source: Data based on primary sources

Figure 5: Risks to which the hotel sector analyzed is exposed.

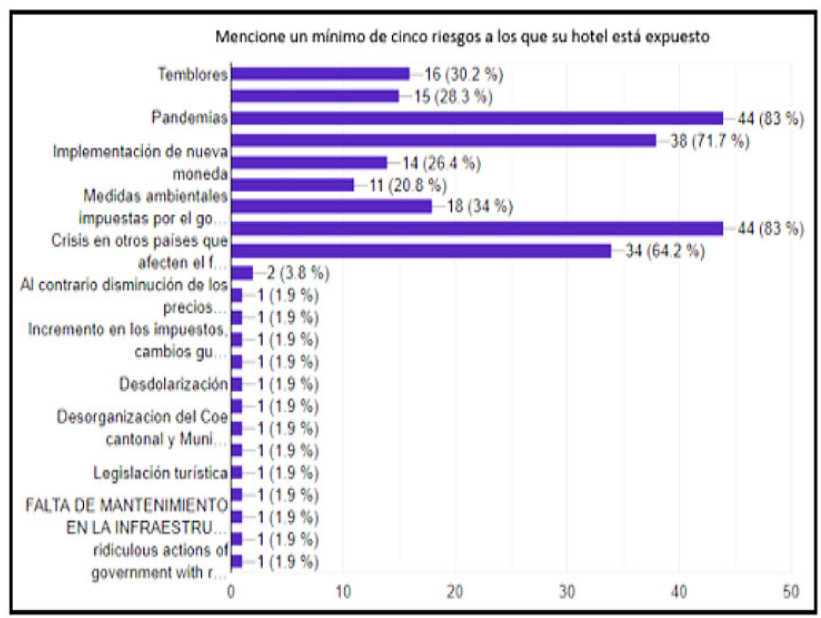

Source: Information based on primary sources 
It was considered appropriate to determine the correlation index between the level of occurrence and impact of the risks, the results of which are shown in the following table:

Table 2: Level of correlation according to occurrence and impact between risks.

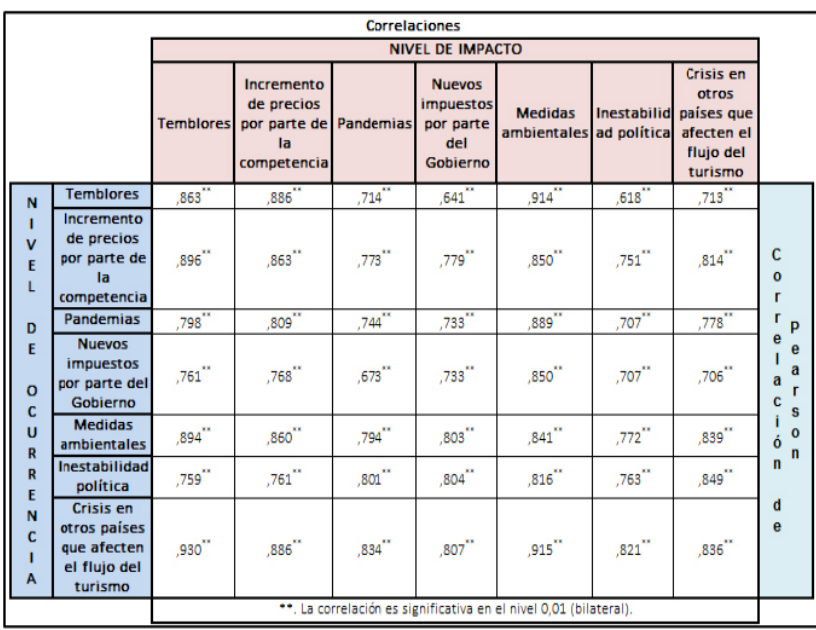

Source: Own elaboration based on primary information

Table 2 determines the correlation that the risks have with each other, through their probability of occurrence and the level of impact they would have on the hotel sector in the event that they materialized.

From the data in Table 2 it can be determined that the risks of greatest occurrence and impact are those that have to do with crises in other countries that affect the flow of tourism with a correlation of 0.930 , environmental measures with a value of 0.914 , the increase in prices by competitors with 0.896 and finally environmental measures with a correlation of 0.894 , these risks being the most representative.
Table 3: Interpretation of the hypothesis test for correlation analysis according to occurrence and impact between risks.

\begin{tabular}{|l|}
\hline \multicolumn{1}{|c|}{ Prueba de hipótesis } \\
\hline HO: r=0 \\
\hline H1: $\neq 0$ \\
\hline Nivel de Significancia: 0,05 \\
\hline Correlación bilateral de Pearson \\
\hline$p>0,05$, Se acepta HO \\
\hline$p<0,05$, Se rechaza HO \\
\hline$p=0,000$ \\
\hline $\begin{array}{l}\text { Se acepta HO, va que existe } \\
\text { correlación positiva entre el nivel de } \\
\text { ocurrencia } y \text { el nivel de impacto de } \\
\text { los riesgos. }\end{array}$ \\
\hline
\end{tabular}

Source: Hypothesis Test Factors

Figure 6: Percentage of the level of occurrence of risks and their impact on the hotel sector.

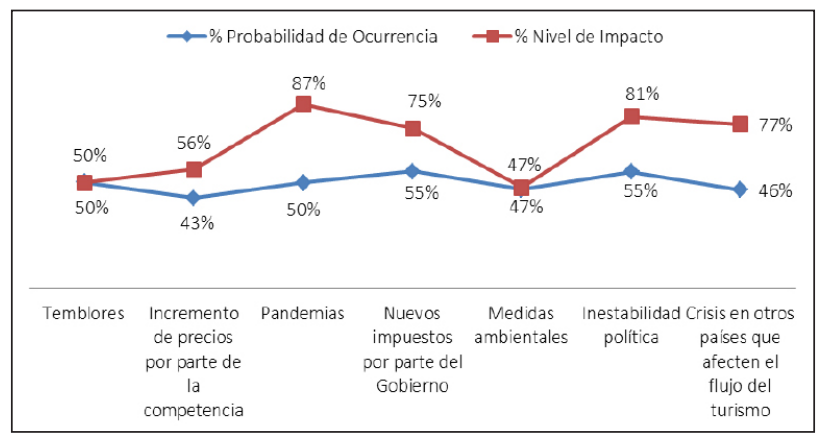

Source: Occurrence level data based on primary sources

An interview questionnaire was also applied to selected experts from the Hotel Association of Azuay, the results of which are shown below: 
Table 4: Responses from interviews with experts.

\begin{tabular}{|c|c|}
\hline question & Answers \\
\hline $\begin{array}{l}\text { What trends can lead } \\
\text { to or accelerate the } \\
\text { coronavirus crisis with } \\
\text { guest-tourists? }\end{array}$ & $\begin{array}{l}\text { *Existence of variants of } \\
\text { the virus. } \\
\text { *Delay in vaccination } \\
\text { processes } \\
\text { *Increased demand for room } \\
\text { service to the detriment } \\
\text { of food service in other } \\
\text { areas of the hotel. } \\
\text { *Buffet food service } \\
\text { was removed. }\end{array}$ \\
\hline $\begin{array}{l}\text { What strategic plans } \\
\text { do hotels have to } \\
\text { reactivate the sector? }\end{array}$ & $\begin{array}{l}\text { *Hotels do not have strategic } \\
\text { plans. }{ }^{*} \text { Hotels must be } \\
\text { certified by the GAD using } \\
\text { biosecurity manuals for } \\
\text { their operation. }\end{array}$ \\
\hline $\begin{array}{l}\text { What strategies have } \\
\text { been implemented or } \\
\text { to be implemented to } \\
\text { combat events similar } \\
\text { to those of the } \\
\text { COVID-19 pandemic? }\end{array}$ & $\begin{array}{l}\text { *Hotels do not have } \\
\text { contingency plans for the } \\
\text { management of external } \\
\text { risks; they only have } \\
\text { occupational risk prevention. }\end{array}$ \\
\hline
\end{tabular}

Source: Interview response based on primary sources.

Once the findings linked to the first research question have been presented, the results linked to the second question are presented as:

\section{2. - How did the "COVID-19" pandemic affect the hotel sector of the city of Cuenca?}

The information is structured showing first of all the results of the correlation index between GDP and sales of the hotel sector for the period 2018-2020, in order to evaluate the level of importance of the contribution of the sector generated by the city to the growth of the country (Table 5). Subsequently, in order to make a comparison between the income generated by accommodation in the three most representative cities of the country, table 6 was prepared; below is the current situation regarding hotel closures perceived by the officials surveyed, figure 6 ; the losses caused to hotels due to the cancellation of reservations during the impact of the pandemic up to the time when the data shown in Figure 7 were lifted are described below.
Considering that one of the most important indicators that can measure the level of impact on the economic and social situation of the locality, the analyses linked to employment are shown in Table 8 and Figure 9.

Table 5: Analysis of bilateral correlation between the GDP of Ecuador vs. Brazil Sales in the hotel sector.

The importance of the contributions of the hotel sector of the city of Cuenca to the gap of the country was determined; the data of the statistical series of both indicators for the period from 2018 to 2020 are taken as a reference.

\begin{tabular}{|c|c|c|c|}
\hline \multicolumn{4}{|c|}{ Correlaciones } \\
\hline & & $\begin{array}{c}\text { PIB anual en } \\
\text { miles de } \\
\text { dólares }\end{array}$ & $\begin{array}{l}\text { Ventas al año en } \\
\text { miles de dólares }\end{array}$ \\
\hline \multirow{5}{*}{$\begin{array}{l}\text { PIB } \\
\text { TRIMESTRAL } \\
\text { Miles de } \\
\text { dólares } \\
\text { (Corrientes) }\end{array}$} & $\begin{array}{l}\text { Correlación de } \\
\text { Pearson }\end{array}$ & 1 &, $911^{\circ}$ \\
\hline & Sig. (bilateral) & &, 000 \\
\hline & $\begin{array}{l}\text { Suma de cuadrados y } \\
\text { productos vectoriales }\end{array}$ & $\begin{array}{r}168138779141 \\
40,916\end{array}$ & 29139563,373 \\
\hline & Covarianza & $\begin{array}{r}152853435583 \\
0,992\end{array}$ & 2649051,216 \\
\hline & $\mathrm{N}$ & 12 & 12 \\
\hline \multirow{5}{*}{$\begin{array}{l}\text { ventas al año } \\
\text { en millones de } \\
\text { USD }\end{array}$} & $\begin{array}{l}\text { Correlación de } \\
\text { Pearson }\end{array}$ & $911^{*}$ & 1 \\
\hline & Sig. (bilateral) & .000 & \\
\hline & $\begin{array}{l}\text { Suma de cuadrados y } \\
\text { productos vectoriales }\end{array}$ & 29139563,373 & 60,888 \\
\hline & Covarianza & 2649051,216 & 5,535 \\
\hline & $\mathrm{N}$ & 12 & 12 \\
\hline
\end{tabular}

Source: MINTUR statistical data (2021).

Table 6: Interpretation of the hypothesis test for Pearson's bilateral correlation analysis.

\begin{tabular}{|l|}
\hline \multicolumn{1}{|c|}{ Prueba de hipótesis } \\
\hline HO: $r=0$ \\
\hline H1: $r \neq 0$ \\
\hline Nivel de Significancia: 0,05 \\
\hline Correlación bilateral de Pearson \\
\hline p>0,05, Se acepta HO \\
\hline $\mathbf{p}<0,05$, Se rechaza HO \\
\hline$p=0,000$ \\
\hline $\begin{array}{l}\text { Se acepta HO, va que existe } \\
\text { correlación positiva fuerte } \\
(0,911)\end{array}$ \\
\hline
\end{tabular}

Source: Own elaboration based on secondary sources. 
Table 7: Variation of income from accommodation in the hotel sector of the most visited cities in Ecuador.

\begin{tabular}{|c|c|c|c|c|c|c|c|c|}
\hline \multicolumn{9}{|c|}{ INGRESOS POR ALOJAMIENTOS } \\
\hline AÑ̄O & \multicolumn{2}{|c|}{2019} & \multicolumn{3}{|c|}{2020} & \multicolumn{3}{|c|}{2021} \\
\hline CIUDAD & Millones USD & $\begin{array}{l}\text { Partcipacion } \\
\text { en el sector }\end{array}$ & Millones USD & $\begin{array}{l}\text { Partcipacion } \\
\text { en el sector }\end{array}$ & $\left\{\begin{array}{l}\text { \% De } \\
\text { reducción } \\
\text { de ingresos }\end{array}\right.$ & Millones USD & $\begin{array}{l}\text { Partcipacion } \\
\text { en el sector }\end{array}$ & $\begin{array}{l}\% \text { De } \\
\text { reducción } \\
\text { de ingresos }\end{array}$ \\
\hline GUAYAQUIL & 104,53 & $25,85 \%$ & 43,76 & $10,82 \%$ & $\cdot 58,14 \%$ & 5,91 & $1,46 \%$ & $.86,49 \%$ \\
\hline QUITO & 113,36 & $28,03 \%$ & 37,74 & $9,33 \%$ & $.66,71 \%$ & 4,56 & $1,13 \%$ & $.87,92 \%$ \\
\hline CUENCA & 33,32 & $8,24 \%$ & 16,62 & $4,11 \%$ & $.50,12 \%$ & 3,4 & $0,84 \%$ & $.79,54 \%$ \\
\hline MANTA & 15,53 & $3,84 \%$ & 8,2 & $2,03 \%$ & $-47,20 \%$ & 1,47 & $0,36 \%$ & $.82,07 \%$ \\
\hline SALINAS & 7,72 & $1,91 \%$ & 2,58 & $0,64 \%$ & $.66,58 \%$ & 0,28 & $0,07 \%$ & $.89,15 \%$ \\
\hline ESMERALDAS & 3,6 & $0,89 \%$ & 1,69 & $0,42 \%$ & $.53,06 \%$ & 0,17 & $0,04 \%$ & $.89,94 \%$ \\
\hline
\end{tabular}

Source: Mintur statistical data collection (2021).

Figure 7: Current situation regarding the closure of hotels in Cuenca.

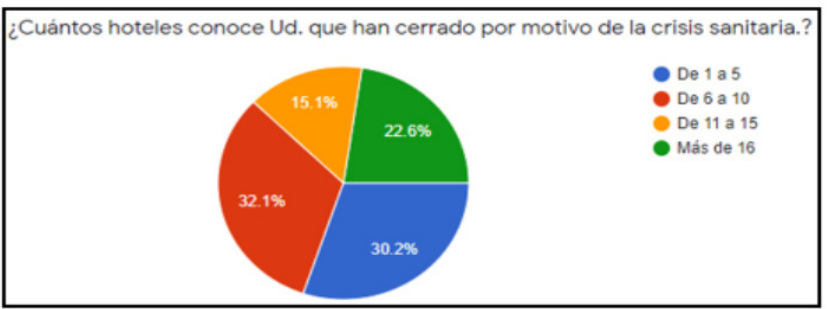

Source: Hotel closure data based on primary sources.

Figure 8: What is the estimated loss in USD due to cancelled bookings in 2020?

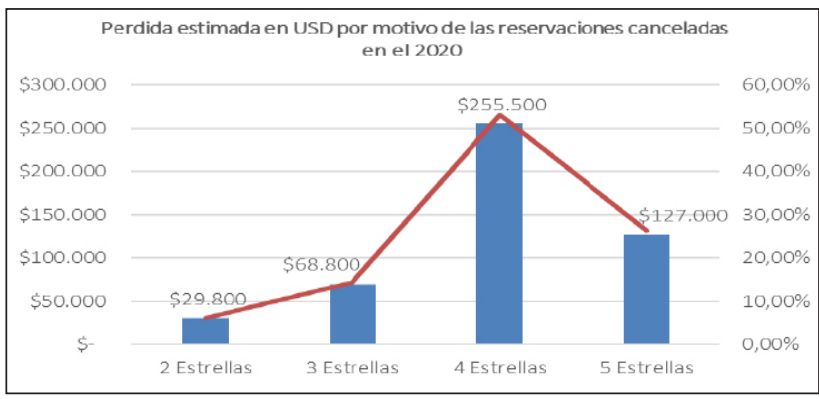

Source: Economic loss data based on primary sources.
Table 8: Statistical data on the variation of employment in hotels in time of pandemic.

\begin{tabular}{|l|r|r|}
\hline & $\begin{array}{c}\text { Estadísticos } \\
\text { Personas que } \\
\text { trabajaban } \\
\text { antes de la } \\
\text { pandemia }\end{array}$ & $\begin{array}{c}\text { Personal con } \\
\text { el que } \\
\text { laboran } \\
\text { actualmente }\end{array}$ \\
\hline \multicolumn{1}{|c|}{ N Válido } & 53 & 53 \\
\hline Media & 12,20 & 3,96 \\
\hline Moda & 8 & 3 \\
\hline Desv. Estándar & 8,00326 & 2,60888 \\
\hline Varianza & 64,052 & 6,806 \\
\hline Minimo & 4 & 2 \\
\hline Máximo & 37 & 12 \\
\hline
\end{tabular}

Source: Statistical data on employment variation based on primary sources.

Figure 9: Trend by standard deviation of unemployment in the hotel sector of Cuenca.

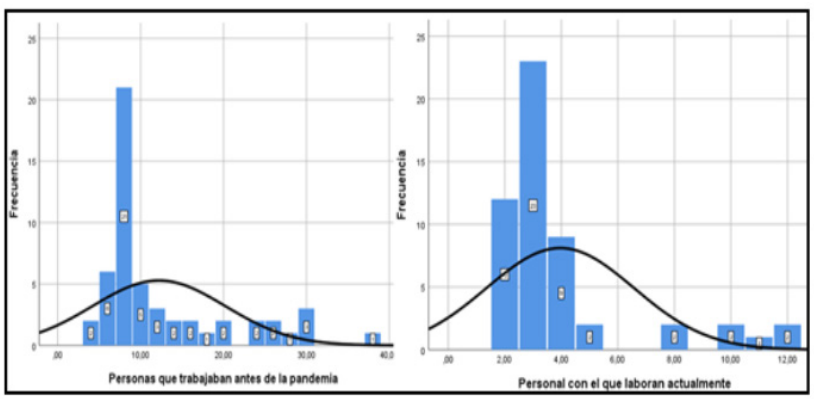

Source: Trend data based on primary sources.

Figure 10: Variation in employment and unemployment in two- to five-star hotels in the city of Cuenca.

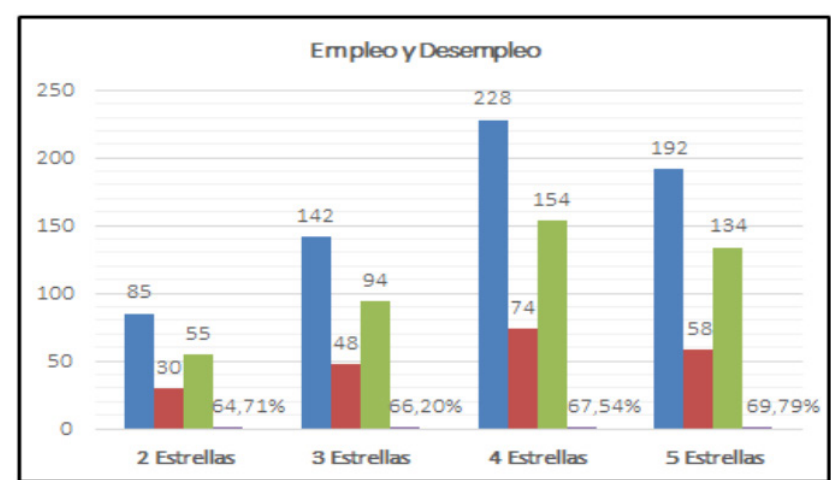

Source: Unemployment variation data based on primary sources. 
As part of the interview questionnaire applied to the selected experts in relation to research question No 2, the following results were shown:

Table 9: Responses from interviews with experts.

\begin{tabular}{|c|c|}
\hline Question & Answers \\
\hline $\begin{array}{l}\text { What has been the } \\
\text { economic impact of } \\
\text { the coronavirus on } \\
\text { the sector so far? }\end{array}$ & $\begin{array}{l}\text { *Reduction in sales between } 80 \% \\
\text { and } 90 \% .{ }^{*} \text { Maximum occupancy rate } \\
\text { of } 8 \% .{ }^{*} \text { Loss of jobs in transport and } \\
\text { tour guides. } \\
{ }^{*} \text { Reduction of staff from } 60 \% \text { to } \\
70 \%\end{array}$ \\
\hline $\begin{array}{l}\text { How the } \\
\text { coronavirus } \\
\text { affected } \\
\text { relationships } \\
\text { between } \\
\text { companies in the } \\
\text { sector has, are } \\
\text { there alliances? }\end{array}$ & $\begin{array}{l}\text { *If there are alliances between } \\
\text { travel agencies, tourist transports } \\
\text { markets and supermarkets. }\end{array}$ \\
\hline $\begin{array}{l}\text { How has the } \\
\text { coronavirus } \\
\text { changed consumer } \\
\text { behaviors? }\end{array}$ & $\begin{array}{l}{ }^{*} \text { Customers request decrease } \\
\text { in rates and discounts. }{ }^{*} \text { Guests } \\
\text { indicate that the quality of service } \\
\text { has declined. }{ }^{*} \text { Customers are more } \\
\text { demanding in safety measures } \\
\text { and request higher standards } \\
\text { of hygiene and infrastructure } \\
\text { modification within hotels. }\end{array}$ \\
\hline $\begin{array}{l}\text { How has the } \\
\text { coronavirus } \\
\text { changed the } \\
\text { view of the hotel } \\
\text { industry? }\end{array}$ & $\begin{array}{l}\text { *You start practicing rural } \\
\text { tourism and eco-tourism, these } \\
\text { are services offered by hotels. }\end{array}$ \\
\hline
\end{tabular}

Source: Own elaboration based on primary sources.

\section{DISCUSSION}

The study carried out clearly shows the economic crisis that hotels are going through, for this reason, it is necessary to promote associative and cooperative strategies in the hotel sector of the city, these strategies must be executed by the accommodation centers in conjunction with the Decentralized Autonomous Government of the canton Cuenca, the Tourism Foundation for Cuenca, the
Directorate of Tourism of Azuay and the Ministry of Tourism of the National Government, in order to focus on the reactivation of the sector to guarantee stability in the offer of tourist-hotel services.

This issue becomes more relevant if the analysis of the results obtained is taken into account, it is possible to observe that the contributions made by the hotel sector of the city of Cuenca to the GDP of Ecuador, shows a significant ratio of 0.911, which expresses that, if one of the variables grows the other will also grow in a similar proportion, this highlights the importance of the sector within the economic growth of Ecuador. According to the forecasts made by Núñez (2021) the economy of the hotel sector for 2021 will grow around $2 \%$, which will undoubtedly also be positive for the country's economy; if policies were strengthened in relation to the economic revival of the sector, this dynamic could most likely increase.

The above, is all the more significant if it is considered that the selected economic indicators show deterioration, which acts negatively on the levels of contribution of the hotel industry to tourism, the activity shows a notable decrease in income, according to this situation it is possible to observe that being Cuenca the third most visited city by tourists in the country, it is also the third with the greatest economic losses in the sector, being below Guayaquil and Quito, which present a reduction in income for the year 2021 of $-86.49 \%$ and $-87.92 \%$ respectively; hence, the study shows that the city of Cuenca, due to the pandemic in 2020 , has increased its losses exponentially, reaching a level of $-50.12 \%$, a situation that is still present until February 2021, when revenues from accommodation centers continue to decrease, generating so far $\$ 3.4$ million, equivalent to a loss in revenue of $-79.54 \%$ compared to previous years.

Thus, the economic losses in the area of room sales alone reach an approximate of $\$ 481,100$ USD; an average of six to ten hotels have been closed in the city, causing the unemployment rate to rise to a level of $67.54 \%$. In this locality the demand for employment by tourism is high, since the city develops high levels of tourist activity derived from the historical-cultural and heritage resources it possesses. As a response to this problem, Hao, Xiao and Chon (2020) highlight as a possible alternative to increase the income of the sector the use of multichannel platfor$\mathrm{ms}$, the implementation of strategies aimed at improving 
e-commerce through communication channels, to be able to contact and attract new customers, they contribute to the reduction of costs in advertising and facilitate direct interaction with customers.

At the same time, the country's fiscal and monetary policies should focus on neutralizing and countering the negative effects caused by COVID-19, to contribute to the revival of the sector's economy; Pinargote and Loor (2021) allude to this problem, emphasizing the need to achieve the coordination of the national, provincial and local government, so that policies focused on risk prevention can be implemented and with it, mitigate the consequences caused by the pandemic, policies aimed at economic reactivation through credits and long-term loans should be applied in this regard, in order to improve the conditions of the study sector and mitigate the effects of the crisis.

It is necessary for local and provincial governments to coordinate actions related to granting credit and longterm loans, to reverse the taxes generated by tourism into investments for society; Félix and García (2020) corroborate that the efforts to reactivate the economy of the sector by the national government have been almost nil, in the face of this, the strategies implemented by the Decentralized Autonomous Governments have been more effective.

On the other hand, the analysis in relation to the treatment of the crisis carried out by Wut, Xu and Wong (2021) reveals the importance of attending to those that occur in the tourist activity, motivated by several causes, especially those that are linked to the hotel sector, but there is no evidence that links the management of crises with a risk management plan, for this reason, this article emphasizes the importance of managing these events properly. Con this aspect, the findings show that $41.5 \%$ of the hotels that the city has do not have strategies for their prevention, which is a cause for concern if it is considered that an organization is much better prepared to withstand its impacts, if it has structured a prevention plan that contributes to take contingency measures, since there is a level of positive correlation between the occurrence of risks and its level of impact on the accommodation service; in this regard, $81.1 \%$ of the respondents consider it important to implement training programs that contribute to the generation of strategies linked to the prevention of risks, both endogenous and exogenous and thus safeguard the integrity of personnel and facilities.

It was also interesting to find that an element to which hoteliers attach greater importance in terms of risks, are those linked to the implementation of new taxes by the government, environmental measures, political instability, crises in other countries that affect the flow of tourism and currently the pandemic, the results show that these uncertainties have a high impact of affectation on hotels, since they decrease the influx of tourists and directly proportionally reduce their income.

It coincides with the assessment of Felix and García (2020) who consider that another type of risk that affects the sector is the closure of borders, such a measure is adopted by the government to preserve health from confinement, here it may be necessary to implement policies that are emphatic in compliance with biosecurity measures, which should contribute to the opening and mobility of people who can meet recreation needs using hotel capacities.

The aforementioned authors also propose that after the health crisis tourist attractions will have image difficulties, for this reason it will be necessary for hotels to invest in advertising strategies using technological means, such as websites and social networks, possibly they will have to resort to price reduction strategies so that they can be more competitive and expand their market segments attracting new customers; to this criterion it is added that, another element that could mitigate current situation, is given by the conclusion of alliances between hotels and local tourism operators that manage the commercialization of natural attractions, stimulating the practice of the modality of nature tourism, the surroundings of Cuenca offer a varied landscape diversity, since the hotels could activate the increase of activities linked to this purpose.

Felix and García (2020) emphasize the importance of anticipating crises, but do not assume risk management as a valid tool to counteract this situation, in contrast to these authors it is considered that this element is of utmost importance, because it helps to identify threats of predictable and un foreseeable situations, so that you can act in time in order to mitigate the impact that these fac- 
tors may cause, therefore, it follows that it is one of the variables that constitutes cause that cause the unwanted effects of the crisis.

\section{CONCLUSIONS}

From the review of the scientific literature it can be evidenced that the crisis is a phenomenon that is present in the management of tourism, of significant importance also, given that this is a very dynamic sector that generates sources of employment and contributions to the growth of the economy, so that greater attention must be paid to its manifestation and evolution, it is sensitive to negative impacts, especially when there is an increase in its level of occurrence, caused by the progressive problems in society and the absence of strategies that foresee its emergence.

The impacts caused by these events act unfavorably on income levels as a result of the decrease in the influx of tourists, resulting in an increase in unemployment, losses for accommodation centers, financing restrictions, loss of qualified employees and the partial or permanent closure of companies, which has been evidenced at present by the crisis as a result of the COVID-19 pandemic; crises are therefore associated with risks, which may have an exogenous or endogenous character, their effect can be mitigated if they are identified in the organization and there is a plan to manage them.

The findings found evidence that the exogenous risk factors to the hotels have a greater impact, the one with the highest probability of occurrence is associated with the variation in the country's government policies, crises in other countries that affect the flow of tourism and currently the pandemic, in these a positive correlation is evidenced about 0.70; hence, emphasis is placed on the desirability and need to establish risk management strategies focused on their prevention and/or mitigation of their negative effects.

These results also show that the hotel sector made up of small and medium-sized enterprises has been seriously affected by the health emergency, mainly in terms of employment, which on average has decreased by $67.54 \%$ and the closure of several establishments in the city due to a lack of tourists, generating up to $53.11 \%$ in economic losses compared to previous years.

Certainly, the global pandemic of COVID-19 has generated serious consequences to the hotel business of the city, in this scenario, entrepreneurs will have to identify opportunities for improvement to consider strategies for joint work with local and national government entities, which contributes to its reactivation through the implementation of public-private collaboration measures that encourage the increase of income and improve thetourist development of thecommunity, taking advantage of the potential of its surroundings to develop alternatives and nature tourism and restructuring its business models implementing technological tools to promote and advertise its products and services.

\section{REFERENCES}

Anon. n.d. "Hotel Management Objectives I Hotel Consulting IHCS." Retrieved October 15, 2020 (https://www.ihcshotelconsulting.com/es/blog/gestion-hotelera/).

World Bank. 2021. "World Bank Home Page — International Development, Poverty Data." Retrieved April 30, 2021 (https://www.bancomundial.org/es/home).

Beltran, Gustavo. 2018. "Security In Hotels and Resorts - Segurilatam." Retrieved March 25, 2021 (https:// www.segurilatam.com/seguridad-por-sectores/ turismo-y-ocio/seguridad-en-hoteles-y-centros-turisticos_20180919.html).

Bernal, César A. 2011. Research Methodology Administration, Economics, Humanities and Social Sciences.

Carlos Andrés Piñeros Villegas, Ing, Msc Mahé González Arias, and Umcccu Lic Juan Diego Ruíz Rodríguez. 2016. "RISK MANAGEMENT AND STRATEGIC ALIGNMENT. HOTEL CASE."

Chan, René Mario Magaña, Jorge Fernando Cámara Gameros, and Francisco Juan Balam Mena. 2015. RISK ANALYSIS OF THE TOURISM SECTOR COMPANIES IN THE SOUTH OF THE STATE OF YUCATAN. 
Cuenca, Alcaldia. 2017. "Meet Cuenca I Tourism Cuenca Ecuador." Retrieved May 29, 2021 (http://cuenca. com.ec/es/conoce-cuenca).

Mayor's Basin. 2018. "Territorial Political Division Of the Canton Cuenca I GAD MUNICIPAL OF THE CANTON CUENCA." Retrieved May 24, 2021 (http://www. cuenca.gov.ec/?q=page_divisionpolitica).

Diaz, Guillermo. 2017. "Tourism and Local Development." STEPS Tourism and Cultural Heritage Magazine 15(2):333-40. doi: 10.25145/j.pasos.2017.15.021.

Felix, Ángel Guillermo, Mendoza, and Nelson García Reinoso. 2020. "Study of Losses and Reactivation Strategies for the Tourism Sector Due to Health Crisis COVID-19, in the Destination Manta (Ecuador)." Revista Internacional De Turismo, Empresa Y Territorio 7(enero-junio):79-103. doi: 10.21071/ riturem.v4i1.12743.

Félix, Ángel, Nelson García Reinoso, and Rafael Vera. 2020. "Participatory Diagnosis of the Tourism Sector in Managing the Crisis Caused by the Pandemic (COVID-19)." Revista Interamericana de Ambiente y Turismo 16(1):66-78. doi: 10.4067/s0718$235 \times 2020000100066$.

GIER. 2019. "Study of the Tourist Demand and Supply of the City of Cuenca Annual Bulletin." Faculty of Economic Sciences, University of Cuenca 8-9.

Hao, Fei, Qu Xiao, and Kaye Chon. 2020. "COVID-19 and China's Hotel Industry: Impacts, a Disaster Management Framework, and Post-Pandemic Agenda." International Journal of Hospitality Management 90(June):102636. doi: 10.1016/j. ijhm.2020.102636.

Hontalvilla-Gericó, Alejandro, Rubén Lado-Sestayo, and Milagros Vivel-Búa. 2018. "Spanish Hotel Sector and Financial Risks: An Analysis of Meliá Hotels International S.A." Spaces 39(6).

Kessler, Gabriel, and Alejandro Prince. 2018. "Security Notebooks." Security Notebooks 14.
Lerbinger, O. 1997. "LERBINGER, O. (1997): The Crisis Manager: Facing a Risk and Responsibility, Mahwah, NJ, Lawrence Erlbaum Associates - Buscar Con Google." The Crisis Manager: Facing a Risk and Responsibility, Mahwah, NJ, Lawrence Erlbaum Associates. Retrieved October 13, 2020 (https://www. google.com/search?sxsrf=ALeKk000A2MwwtrxyGcD5qlHgsaWRnbJmQ\%3A1602646709207\&ei=tXKGX-6eDMKL5wL9paWYCA\&q=LERBINGER\%$2 \mathrm{C}+0 .+\% 281997 \% 29 \% 3 \mathrm{~A}+\mathrm{The}+\mathrm{crisis}+\mathrm{Ma}-$ nager\%3A+Facing+a+Risk+and+Responsibility\%2C++Mahwah\%2C+NJ\%2C+Lawrence+Erlbaum+Associates\&oq=LERB).

Luque Aranda, Marta, and Carmelo Pellejero Martínez. 2019. "Private Promotion of Tourism in Spain in the First Third of the 20th Century: Tourist Information Offices." Investigaciones de Historia Economica 15(1):38-46. doi: 10.1016/j.ine.2017.10.001.

Maciel, Débora Alves, Marrielle Maia, Andrei Koerner, Par Engstrom, Sandra Borda Guzmán, Nelson Camilo Sánchez, Sandra Serrano, Luis Daniel Vázquez, and Andrés Serbin. 2020. "Latin America and the Impact of the COVID-19 Pandemic."

Mendenhall, William, Robert Beaver, and Barbara Beaver. 2010. Introduction to Probability and Statistics.

MINTUR. 2021. "Sales Visualizer - MINTUR Services Portal." Retrieved May 5, 2021 (https://servicios.turismo.gob.ec/visualizador-ventas).

Muñiz, Diego, and José Brea. 2010. "Crisis Management in Tourism: The Emerging Face of Sustainability." Encontros Científicos Magazine - Tourism \& Management Studies.

United Nations. 2017. "Statistical Commission." Economic and Social Council Magazine.

Núñez, Jean Pierre Alarcón. 2021. "Universidad Técnica De Ambato." Repo.Uta.Edu.Ec 130.

UNWTO, Roprt. 2020. "The Impact of COVID-19 on World Tourism is evident in UNWTO Data on the Cost of Paralysis." Press Release (34):2020-21. 
PAHO/WHO. 2020. "Epidemiological Update Novel Coronavirus (COVID-19)." Pan American Health Organization 1-9.

Pinargote, Karen, and Temístocles Loor. 2021. "Covid-19 and Its Economic Impact on Hotel Companies in Manta-Ecuador." 12:152-68.

UNDP. 2020. "The Economic Impacts of Covid-19 and Inequalities Recommendations." 31.

Pousada, Rafael Vallejo, Elvira Lindoso-Tato, and Margarita Vilar-Rodríguez. 2020. "The Historical Origins of Tourist and Tourism in Spain: Tourist Demand in the Nineteenth Century." Investigaciones de Historia Economica 16(1):12-22. doi: 10.1016/j. ihe.2018.03.001.

Romero, Fernández Ariel. 2003. "Management and Prevention of Occupational Risks in Hotels $\bullet$ Gestiopolis." Retrieved March 25, 2021 (https://www. gestiopolis.com/gestion-y-prevencion-de-riesgos-laborales-en-hoteles/).

Sampieri, Robert. 2018. Research Methodology.
Tourism, Ministry of. 2021. "Movement Visualizer MINTUR Services Portal." 2021. Retrieved May 1, 2021 (https://servicios.turismo.gob.ec/visualizador-movimientos).

Tourism, Institute for Quality. 2020. "Measures to Reduce Infection by the SARS-CoV-2 Coronavirus." 26.

UTPL. 2020. "The COVID-19 Pandemic May Affect National Tourism Revenues by 30\% | Blog." Retrieved May 5, 2021 (https://noticias.utpl.edu.ec/la-pandemia-por-covid-19-puede-afectar-en-un-30-alos-ingresos-del-turismo-nacional).

Woods, R., y D. Viehland. 2000. "Women in Hotel Management." The Cornell Hotel and Restaurant Administration Quarterly 41(5):51-54. doi: 10.1016/ s0010-8804(01)80005-7.

Wut, Tai Ming, Jing (Bill) Xu, and Shun mun Wong. 2021. "Crisis Management Research (19852020) in the Hospitality and Tourism Industry: A Review and Research Agenda." Tourism Management 85:104307. 